\title{
Problematika Sistem Pembelajaran Kombinasi Daring dan Luring Pada Mata Pelajaran Sosiologi Kelas XI IPS di SMA Pada Masa Pandemi Covid-19
}

\author{
Yosi Azari ${ }^{1}$, Delmira Syafrini ${ }^{2}$, Nurlizawati Nurlizawat ${ }^{3}$ \\ 1,2 Universitas Negeri Padang \\ Email: yosiazari68@gmail.com, delmirasyafrini@fis.unp.ac.id
}

\begin{abstract}
Abstrak
Latar belakang penelitian ini adalah problematika sistem pembelajaran kombinasi daring dan luring pada mata pelajaran sosiologi, tujuan penelitian ini adalah untuk menjelaskan problematika sistem pembelajaran kombinasi daring dan luring pada mata pelajaran sosiologi kelas XI IPS di SMA Negeri 1 Ranah Pesisir, Adapun dalam penelitian ini menggunakan dua teori yang pertama teori struktural fungsional oleh Talcott Parsons, di dalam teori ini terdapat konsep AGIL. Penelitian ini menggunakan pendekatan penelitian kualitatif, dengan tipe penelitian studi kasus, pemilihan informan dilakukan secara purposive sampling dengan 20 orang informan, pengumpulan data secara observasi. Wawancara mendalam, dan studi dokumentasi. Data Reduction (Reduksi Data), Data Display (Penyajian Data), dan Conclusion Drawing/ Verification (Penarikan Kesimpulan). Lokasi penelitian di SMA Negeri 1 Ranah Pesisir, Kabupaten Pesisir Selatan. Hasil penelitian yang peneliti lakukan selama berada di lapangan yaitu di SMA Negeri 1 Ranah Pesisir pelaksanaan pembelajaran kombinasi daring dan luring memilki problematika yang dirasakan siswa adalah 1) Siswa kesulitan dalam menyesuaikan diri terhadap pembelajaran kombinasi, 2) Keterbatasan sarana dan prasarana dalam pelaksanaan pembelajaran kombinasi daring/luring, 3) Kurangnya motivasi siswa dalam pembelajaran kombinasi daring/luring, 4) Hasil belajar siswa rendah , 5) Siswa tidak mampu membeli paket internet, 6) Kesulitan siswa dalam mengakses jaringan internet. dan guru dalam melaksanakan sistem pembelajaran kombinasi daring/luring. adapun problematika sistem pembelajaran kombinasi daring/luring pada mata pelajaran sosiologi yang berasal dari guru yaitu: 1) Guru tidak memiliki skill/pengetahuan dalam pembelajaran kombinasi daring/luring, 2) Guru kesulitan dalam memberikan penilaian pada pembelajaran kombinasi, 3) Tidak efektifnya waktu mengajar guru, 4) kemampuan guru sosiologi menggunakan teknologi informasi terbatas, 5) Keterbatasan sarana dan prasarana.
\end{abstract}

Kata Kunci: Covid-19, Guru, Pembelajaran Kombinasi, Problematika Pembelajaran, Siswa

\begin{abstract}
The purpose of this study is to explain the problems of the combined online and offline learning system in sociology class XI IPS subjects at SMA Negeri 1 Ranah Pesisir, this is interesting to study because SMA Negeri 1 Ranah Pesisir is one of the schools in West Sumatra implementing a learning system online/oftline during the Corona virus pandemi. But in the implementation of the learning experience problems. As for this study, two theories are used, the first is the structural functional theory by Talcott Parsons in this theory there is the AGIL consept and the second is the Landa learning theory which discusses technology in the implementation of online learning, this research uses a qualitative research approach, with the type of case study research, the selection of informants is carried out by purposive sampling with twenty people informant, observational data collection indepth interviews and documentation studies. Data reduction, data display, conclusion drawing/verification. The research location is in SMA Negeri 1 Ranah Pesisir Kabupaten Pesisir Selatan. the result of the research that the researchers did while in the field, ini SMA Negeri 1 Ranah Pesisir implementing a combination online/offline learning system ini sociology subjects. Then it can be concluded that the problems of the online/offline combination learning system that are felt by students and teachers.
\end{abstract}

Keywords: Combination Learning, Covid-19, Learning Problems, Student, Teacher

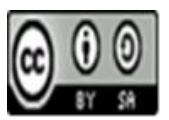


Yosi Azari, Delmira Syafrini, Nurlizawati Nurlizawati Problematika Sistem Pembelajaran Kombinasi Daring dan Luring Pada Mata Pelajaran Sosiologi Kelas XI IPS di SMA Negeri 1 Ranah Pesisir

\section{Pendahuluan}

Bupati Pesisir Selatan mengeluarkan surat edaran tentang Panduan pembelajaran TK/RA, SD/MI, SMP/MTs dan SMA, SMK, MA di masa Pandemi Covid-19 pada tahun Pelajaran 2020/2021. Dengan hal itu maka pemerintah Bupati Pesisir Selatan mengeluarkan surat edaran tetang pembelajaran 2020/2021 dengan penerapan pembalajaran sistem daring/luring, Pembelajaran daring artinya adalah pembelajaran yang dilakukan secara online, menggunakan aplikasi pembelajaran maupun jejaring sosial. Pembelajaran daring merupakan pembelajaran yang dilakukan tanpa melakukan tatap muka, tetapi melalui platform yang telah tersedia. Segala bentuk materi pelajaran didistribusikan secara online, komunikasi dan tes juga dilakukan secara online. Sistem pembelajaran melalui daring dibantu dengan beberapa aplikasi, seperti Google Classroom, Google Meet, Emodo dan Zoom. Sedangkan pembelajaran luring merupakan singkatan dari pembelajaran di luar jaringan atau dengan istilah offline, artinya pembelajaran ini tidak lain merupakan pembelajaran konvensional yang sering digunakan oleh guru sebelum adanya pandemi Covid-19 akan tetapi ada perubahan tertentu seperti jam belajarnya lebih singkat dan materinya sedikit.

Bedasarkan hasil pengamatan awal peneliti melihat dalam proses pembelajaran kombinasi daring/luring pada mata pelajaran sosiologi di masa pandemi Covid-19, di SMA Negeri 1 Ranah Pesisir menggunakan berbagai cara supaya pembelajaran sosiologi tetap berjalan, dalam penerapan pembelajaran memiliki permasalahan yang datang dari guru dan siswa. Berdasarkan surat edaran Bupati Pesisir Selatan dikatakan bahwa ada aturan dalam pelaksanaan proses belajar daring/luring bahwa diantaranya yang mana di dalam kelas jumlah siswa maksimal 50\% per kelas (10 orang kelas rendah, 14 orang kelas tinggi jejang SD, dan 16 orang jenjang SMP dan SMA), dan waktu belajar lebih sedikit. Berdasarkan hal itu supaya pembelajaran sosiologi bisa terlaksana maka dalam penerapannya membagi siswa berdasarkan nomor absen ganjil dan nomor absen genap siswa, dengan berdasarkan nomor absen tersebut dibagi dua setiap minggunya jumlah siswa di kelas hanya diperbolehkan berjumlah 16 orang, itu merupakan alternatife sistem pembelajaran kombinasi pada mata pelajaran sosiologi di SMA Negeri 1 Ranah Pesisir supaya pembelajaran tetap terlaksana. (Wahyuningsih, Hindu, Gusti, \& Sugriwa, 2021)

Dengan penerapan pembelajaran yang diungkapkan bahwa di SMA Negeri 1 Ranah Pesisir melaksanakan pembelajaran dengan sistem ganjil genap, satu minggu daring dan satu minggu luring. Pembelajaran daring yang dilaksanakan melalui aplikasi whatsaap group, tidak efektif karena siswa banyak tidak mengikuti pembelajaran sedangkan pembelajaran luring dilakukan dengan tatap muka di kelas yang mana pada tatap muka guru menerangkan pembelajaran saja.

Beberapa penelitian yang telah dilakukan oleh beberapa peneliti sebelumnya diantaranya: Penelitian yang dilakukan oleh Andi Asywid Nur (2020) Universitas Makassar "Problematika Guru Dalam Pembelajaran Daring Di Tengah Pandemi Covid-19 Studi Kasus Guru IPS SMPN 3 Selayar", penelitian ini menunjukkan pada problematika guru IPS SMP 3 Selayar dalam pembelajaran daring yang mana pelaksanaan pembelajaran memiliki keterbatasan baik pada guru maupun siswa, selanjutnya penelitian yang dilakukan oleh Nur Millati Aska Sekha Apriliana (2020) IAIN Salatiga " Problematika Pembelajaran Daring Pada Siswa kelas IV Mi Bustanul Mubtadin Kecamatan Suruh Kabupaten Semarang", penelitian ini menunjukkan pada pembelajaran daring memiliki problematika yang muncul dalam pembelajaran dari di MI ini karena banyak diantaranya siswa tidak memahami pembelajaran dan tidak pernah menerapkan pembelajaran sebelumnya, kemudian penelitian yang dilakukan oleh Izza Umaroh (2021) UIN Sunan Ampel Surabaya " Problematika Pembelajaran Daring Masa Pandemi Covid-19 Mata Pelajaran Pendidikan Agama Islam (PAI) bagi Peserta Didik di SMP Negeri 23 Surabaya" penelitian ini menunjukkan problematika pembelajaran daring masa pandemi Covid-19 pada mata pelajaran Pendidikan Agama Islam. Artikel ini bertujuan untuk menjelaskan problematika sistem pembelajaran kombinasi daring/luring pada mata pelajaran sosiologi kelas XI IPS di SMA Negeri 1 Ranah Pesisir. 
Yosi Azari, Delmira Syafrini, Nurlizawati Nurlizawati Problematika Sistem Pembelajaran Kombinasi Daring dan Luring Pada Mata Pelajaran Sosiologi Kelas XI IPS di SMA Negeri 1 Ranah Pesisir

Pada Masa Pandemi Covid-19

\section{Metode Penelitian}

Pendekatan penelitian yang digunakan adalah pendekatan kualitatif. Pengertian pendekatan penelitian kualitatif menurut Sugiyono (Sugiyono, 2015) adalah penelitian yang lebih menekankan pada makna dari suatu masalah. Tipe penelitian yang digunakan studi kasus, penelitian studi kasus ini adalah untuk mendeskripsikan atau menggambarkan data yang telah terkumpul ketika peneliti mendeskripsikan problematika sistem pembelajaran kombinasi daring dan luring pada mata pelajaran sosiologi kelas XI IPS di SMA Negeri 1 Ranah Pesisir.

Pemilihan informan digunakan secara purpose sampling, menurut Sugiyono (Sugiyono, 2015) menetapkan informan ditentukan oleh peneliti sendiri agar bisa mengumpulkan data di lapangan sesuai dengan kebutuhan peneliti dengan cara melihat langsung realita yang ada di lapangan. Dalam penelitian ini peneliti mememilih informan sebanyak 20 orang yaitu 1 orang kepala sekolah, wakil 1 orang kurikulum, 1 orang wakil kepala sekolah, 1 orang guru mata pelajaran sosiologi serta 16 orang siswa kelas XI IPS 16 orang.

Pengumpulan data yang peneliti lakukan dalam penelitian ini adalah dengan observasi, wawancara dan studi dokumentasi, jadi jenis observasi yang dipilih adalah yang digunakan dalam penelitian ini adalah observasi partisipasi pasif (Sugiyono, 2017), yakni peneliti melihat secara langsung kegiatan belajar pada masa pandemi Covid -19 serta permasalahan yang dialami selama proses pembelajaran. Peneliti hadir dalam pelaksanaan pembelajaran, tetapi tidak berpartisipasi hanya sebatas mengamati. Penelitian ini dilakukan selama jam pelajaran aktif dan diluar pembelajaran aktif. Pada awal observasi peneliti meminta izin kepada kepala sekolah dan diteruskan kepada wakil kepala sekolah serta guru. Observasi yang dilakukan adalah kegiatan guru dalam pelaksanaan pembelajaran di kelas daring maupun luring, proses belajar mengajar, siswa, situasi dan kondisi kelas saat belajar. Selanjutnya teknik wawancara, wawancara yang dipilih dalam penelitian ini adalah wawancara mendalam (indepth interview) untuk mendapatkan data secara rinci dan data yang relevan sesuai dengan tujuan penelitian wawancara mendalam ini bersifat tidak berstruktur, yang mana pelaksanaanya tanya jawab mengalir seperti dalam percakapan sehari-hari. Wawancara dilakukan dengan mengajukan pertanyaan sesuai dengan situasi dan kondisi di lapangan, namun tidak menyimpang dari rencana penelitian yang telah dirumuskan (Subayo, 2006). Wawancara dilakukan kepada 1 orang guru sosiologi, wakil kesiswaan, kepala sekolah, wakil kurikulum serta 16 orang siswa sosiologi. Wawancara dengan guru sosiologi dan siswa dilakukan pada saat jam sekolah yaitu saat jam pelajaran sosiologi dan wawancara dengan wakil kurikulum dilakukan ketika jam istirahat, dan begitu juga dengan kepala sekolah serta wakil kesiswaan. Kemudian studi dokumentasi, menurut Suharsimi Arikunto (Arikunto, 2016) dokumentasi adalah mencari dan mengumpulkan data mengenai hal-hal yang berupa catatan, transkip, buku, surat kabar, majalah, notulen, rapor, agenda, dan sebagainya. Dokumentasi yang peneliti kumpulkan adalah hasil belajar dan daftar absensi peserta didik.

Pengujian keabsahan data dalam penelitian ini menggunakan teknik trianggulasi data dilakukan untuk menguji data dengan cara mnegecek data atau informasi dari berbagai sumber. Trianggulasi data dilakukan untuk memperkuat data yang diperoleh dari lapangan, maka penelitian ini menggunakan jenis trianggulasi sumber dilakukan dengan cara mengajukan beberapa pertanyaan yang sama kepada informan untuk mendapatkan data yang sama. Trianggulasi metode dilakukan dengan membandingkan hasil observasi, wawancara dan dokumentasi, sehingga memperoleh data yang valid.

Teknik analisis data dalam penelitian ini menggunakan analisis Miles dan Huberman yaitu reduksi data, penyajian data, dan kesimpulan. Langkah-langkah dalam menganalisis data yaitu: peneliti merangkum hasil dari observasi, wawancara dan dokumentasi yang dianggap penting; setelah hasil penelitian dirangkum, peneliti melakukan analisis deskriptif yang dikaitkan dengan teori; setelah data terkumpul, dirangkum dan dianalisis deskriptif serta dikaitkan dengan teori, data disimpulkan. Data disimpulkan untuk memberikan makna terhadap data yang telah dianalisis. (Putria, Maula, \& Uswatun, 2020) 
Yosi Azari, Delmira Syafrini, Nurlizawati Nurlizawati Problematika Sistem Pembelajaran Kombinasi Daring dan Luring

\section{Hasil dan Pembahasan}

Dalam pelaksanaan pembelajaran pada masa pandemi Covid-19 yang dilaksanakan secara mendadak dan tidak ada persiapan baik guru maupun siswa. Yang mana dalam pelaksanaan pembelajaran ini waktu lebih pendek dan materinya sedikit, sehingga muncul problem baik yang berasal dari guru maupun siswa.

\section{Problematika Sistem Pembelajaran Kombinasi Daring/Luring yang berasal dari siswa}

\section{Siswa kesulitan dalam menyesuaikan diri terhadap pembelajaran kombinasi}

Pembelajaran kombinasi diterapkan secara mendadak tanpa persiapan yang dilakukan oleh siswa, yang mana pada pembelajaran kombinasi daring/luring siswa harus bisa memahami teknologi, pada pembelajaran kombinasi waktu lebih sedikit yang mana waktu 1 jam hanya 30 menit, pembelajaran kombinasi bergantian setiap sesinya setiap siswa berjumlah 16 orang antara daring dengan luring.

Untuk menjawab bagaimana problematika pelaksanaan pembelajaran pada masa pandemi Covid-19 dapat dijelaskan dengan perspektif teori struktural fungsional yang dikemukakan oleh Talcott Parsons. Menurut Talcott Parsons dalam (Ritzer, G., 2008) struktur sosial dan pranata sosial berada dalam suatu sistem sosial yang berdiri atas bagian-bagian atau elemen-elemen yang saling berkaitan dan menyatu dalam keseimbangan. Asumsi dari teori ini menganggap bahwa setaip struktur dalam sistem sosial, fungsional terhadap yang lain, sebaliknya kalau tidak fungsional maka struktur itu tidak aka nada atau hilang dengan sendirinya. Selanjutnya dalam pandangan Parsons sebuah sistem membutuhkan 4 fungsi penting agar tetap berada pada posisi seimbang yaitu: Adaptation (adaptasi), Goal attainment (Pencapaian Tujuan), Integration (Integrasi), dan Latency (Pemeliharaan Pola).

Hal senada juga diungkapkan oleh AD selaku kepala sekolah SMA Negeri 1 Ranah Pesisir.

“... pembelajaran kombinasi juga diterapkan di SMA Negeri 1 Ranah Pesisir sejak April 2021, penerapan pembelajarannya dengan system pembelajaran kombinasi daring/luring, sekolah harus menerapkan pembelajaran ini sesuai dengan aturan pemerintah, penerapannya dengan satu minggu daring dan satu minggu luring pembagiannya berdasarkan absen siswa dengan ganjil genap..." Wawancara 8 April 2021)

Hal diatas juga dikatakan oleh Ibu YN (40 Tahun) yang mengatakan bahwa:

“... Sejak pembelajaran kombinasi daring dan luring diterapkan di SMA Negeri 1 Ranah Pesisir, maka berdampak bagi siswa sosiologi, banyak diantaranya siswa tidak paham dengan pembelajaran daring dan luring sehingga sulit siswa untuk mengikuti pembelajaran dan susah siswa untuk menyesuaikan dengan pembelajaran daring/luring karena pembelajaran ini belum pernah diterapkan pada mata pelajaran sosiologi sebelumnya yosi..." (Wawancara 8 April 2021).

Jadi berdasarkan informasi yang didapatkan dari YN, dapat dikatakan bahwa problematika ditemui saat pembelajaran darin dan luring, yaitu siswa kesulitan dalam memahami pembelajaran daring/luring, siswa kesulitan dalam menyesuaikan terhadap pembelajaran daring dan luring.

\section{Keterbatasan sarana dan prasarana dalam melaksanakan sistem pembelajaran kombinasi}

Daring dan luring. Kurangnya sarana dan prasarana dalam melaksanakan pembelajaran menjadi masalah yang sangat penting karena bisa tidak mencapai tujuan yang di inginkan. Berdasarkan hal itu sarana prasarana digunakan untuk menunjang pembelajaran supaya pembelajaran terlaksana dengan baik, agar tujuan pembelajaran tercapai, apalagi dalam pelaksanaan sistem pembelajaran kombinasi daring dan luring yang mana sarana prasarana harus 
memadai dan lengkap, seperti sekolah menyediakan fasilitas yang cukup, siswa memiliki fasilitas yang memadai sumberdaya manusia mendukung, pengetahuan terhadap pembelajaran sudah banyak, maka pembelajaran akan tercapai dan tidak terkendala apapun.

Berbeda penerapannya pada sistem pembelajaran kombinasi daring/luring yang mana dalam pelaksana pembelajaran kombinasi daring/ luring ini merupakan system pembelajaran yang diterapkan diterapkan pada mata pelajaran sosiologi yang mana sarana dan prasarana sangat terbatas sehingga siswa kesulitan untuk mengikuti pembelajaran. Yang mana sekolah tidak menyediakan fasilitas untuk menunjang pembelajaran, sekolah tidak menyediakan buku untuk pembelajaran tatap muka, ketersedian buku paket di sekolah terbatas, dan materi di dalam buku tidak lengkap untuk pembelajaran sosiologi sehingga siswa tidak bisa menggunakan buku dalam melaksanakan pembelajaran di rumah maupun di sekolah (Asmuni, 2020). Siswa dalam pelaksanaan pembelajaran daring juga tidak memiliki fasilitas yang lengkap seperti pembelajaran daring memerlukan handphone, laptop, paket internet yang cukup karena hal itu siswa tidak memiliki fasilitas yang cukup untuk sistem pembelajaran kombinasi daring/ luring ini, karena keterbatasan fasilitas yang dimilki sekolah tidak mencukupi dan fasilitas siswa juga tidak memadai sehingga pembelajaran kombinasi daring/ luring berjalan dengan seadanya sehingga banyak permasalahan yang dialami siswa dan begitu juga dengan guru mata pelajaran sosiologi. Hal ini sesuai yang dikatakan oleh Ibuk YN yang mengatakan bahwa:

“... Untuk pembelajaran kombinasi daring/ luring ini sekolah tidak menyediakan buku yang cukup untuk mata pelajaran sosiologi, buku yang ada di perpustakaan tidak cukup dan materi yang ada dibuku terkadang ada dan kadang tidak ada, sehingga siswa tidak bisa meminjam buku untuk dibawa pulang dan siswa tidak mempunyai panduan dalam pembelajaran kombinasi apalagi pada pembelajaran daring siswa juga tidak mempunyai fasilitas handpohone laptop serta jaringan yang susah, oleh karena itu siswa sulit untuk mengikuti pembelajaran daring, sehingga siswa belajar di rumah dengan cara membuat tugas yang diberi guru ketika pembelajaran luring serta disuruh membaca seperti bahan ajar di rumah..." (Wawancara 8 April 2021).

Apa yang dikatakan oleh Ibu YN (40 Tahun) diatas juga dikatakan oleh ND (16 Tahun) selaku siswa kelas XI IPS 3 yang mengatakan bahwa:

“... dalam pembelajaran daring/luring ini kak kami banyak membuat tugas di rumah kak, apalagi pada mata pelajaran sosiologi kak harus membaca buku kak, kami pinjam buku di perpustakaan kak untuk membuat tugas di rumah kak, dan buku sosiologi tidak cukup kak dan tidak lengkap materi di dalamnnya kak, dan juga ketika belajar daring kami tidak bisa kak karena tidak mempunyai handphone kak..." (Wawancara 7 April 2021). bahwa:

Hal serupa juga dikatakan oleh YS (16 Tahun) selaku siswa kelas XI IPS, YS mengatakan "...saya tidak punya handphone untuk belajar daring kak, apalgi laptop kak..."

Berdasarkan wawancara peneliti dengan informan diatas bawa dalam pelaksanaan pembelajaran daring/ luring, yang mana dalam pembelajaran daring siswa diberi tugas untuk belajar di rumah dan membaca buku di rumah, berdasarkan hal itu siswa meminjam buku diperpustakaan sekolah buku tidak tersedia karena jumlah buku terbatas, dengan hal ini siswa beranggapan bahwa sekolah tidak menyediakan sarana dan prasarana untuk menunjang pembelajaran pada masa pandemi Covid-19 ini, dan siswa juga tidak memiliki fasilitas seperti handphone untuk mengikuti pembelajaran daring. 
Yosi Azari, Delmira Syafrini, Nurlizawati Nurlizawati Problematika Sistem Pembelajaran Kombinasi Daring dan Luring

\section{Kurangnya motivasi siswa dalam belajar}

Berdasarkan observasi yang peneliti lakukan ketika pembelajaran luring belajar dilaksanakan di dalam kelas banyak diantaranya siswa tidak hadir di dalam kelas karena mereka malas untuk datang kesekolah dan banyak tugas, mereka takut ditagih tugas oleh guru, bahkan ada yang hadir tetapi tidak memperhatikan pembelajaran berlangsung kehadiran mereka kesekolah hanya untuk mengambil absensi dan untuk bermain kesekolah, ketika pembelajaran berlangsung ada diantarnya siswa main handphone dan mempunyai kesibukkan masing-masing dan membuat tugas mata pelajaran lain sehingga tidak fokus kepada mata pelajaran sosiologi dan bahkan ada siswa yang tidur di kelas sehingga tidak memperhatikan pelajaran ada yang pergi izin untuk makan di kantin. Ketika belajar kelompok belajar luring hanya mengandalkan satu orang teman karena mereka merasa malas untuk belajar kurang motivasi, dan merasa terbebani dengan tugas sehingga tidak membuat tugas sama sekali.

Hal ini dikatakan oleh Ibuk YN (40 Tahun) selaku guru mata pelajaran sosiologi:

“...sejak diterapkan system pembelajaran kombinasi daring/luring pada siswa sosiologi kelas XI banyak siswa kurang motivasi dalam belajar apalagi bagi siswa yang malas bahkan tambah malas untuk belajar, banyak waktu dipergunakan siswa untuk bermain si selama pembelajaran daring, kalau pembelajaran daring sama saja dengan tidak belajar karena siswa hanya bisa dikasih tugas dan itu ada yang mengerjakan tugas ada yang tidak si, kalau pembelajaran online dilaksanakan melalui zoom yang hadir 1 dan 2 orang si. Dan begitu juga dikelas ada siswa yang datang terlambat bahkan waktu habis karena terlambat, dan di dalam kelas siwa banyak tidur main handphone dan mintak izin untuk makan di kantin, sehingga malas untuk belajar dan menghindar untuk belajar selama proses belajar hanya menunggu jam pelajaran habis..." (Wawancara 8 April 2021)

Hal serupa juga dikatakan oleh AT (16 Tahun) yang mengatakan bahwa:

"... kita malas untuk sekolah kak, banyak tugas kak dan tugas yang diberikan banyak kak ada yang mengerti dan ada yang ngak kak, sehingga kami malas untuk datang kesekolah kak itu makanya kami lambatkan pergi sekolah kak supaya jam habis kak, kadang takut sama guru kak karena terlalu banyak tugas tidak dikerjakan kak, kita dikejar-kejar tugas kak..." (Wawancara 7 April 2021)

Hal serupa juga dikatakan oleh RH (16 Tahun).

“... kami datang kesekolah hanya bosan di rumah kak, tidak untuk belajar kak bermain untuk bermain dengan kawan-kawan kak, karena tugas banyak kak dan bingung mengerjakan tugas yang mana kak..." (Wawancara 7 April 2021)

Jadi berdasarkan wawancara peneliti dengan informan dapat disimpulkan bahwa dalam pelaksanaan system pembelajaran kombinasi daring/luringbanyak diantaranya siswa banyak kurang motivasi dalam belajar sejak diterapkan sistem pembelajaran ini, karena siswa merasa banyak tugas sehingga takut untuk datang kesekolah, tugas tidak pernah dikerjakan oleh siswa dan begitu juga waktu belajar tatap muka atau luring banyak diantaranya siswa tidak memperhatikan pembelajaran karena sudah merasa bosan dan jenuh untuk belajar sehingga siswa banyak keluar masuk dalam waktu belajara sibuk masing-masing, serta siswa ada yang tidur di dalam kelas, pergi makan ke kantin.

\section{Hasil belajar siswa rendah.}

Berdasarkan hal itu selama masa pandemi Covid-19 dengan system pembelajaran yang diterapakan kombinasi daring/luring pada mata pelajaran sosiologi, maka hasil belajar siswa 
Yosi Azari, Delmira Syafrini, Nurlizawati Nurlizawati Problematika Sistem Pembelajaran Kombinasi Daring dan Luring Pada Mata Pelajaran Sosiologi Kelas XI IPS di SMA Negeri 1 Ranah Pesisir

banyak yang rendah oleh sebab itu dengan proses pembelajaran siswa yang tidak stabil diantaranya ada siswa yang tidak hadir dalam pembelajaran, tidak membuat tugas, tidak belajar di rumah, tidak aktif dalam belajar, maka berdasarkan hal itu banyak nilai siswa yang turun selama pembelajaran kombinasi daring/luring ini bahkan mencapai 50\% jika dibandingkan dengan nilai siswa belajar normal seperti dulu sebelum masa pandemi Covid-19. (Dewi, 2020). Dengan hal itu banyak siswa sosiologi kelas XI tidak antusias dalam mengerjakan tugas apalagi dalam pelaksanaan ujian, banyak diantaranya siswa tidak serius dalam mengerjakan ujian bahkan ada kertas kosong yang siswa kumpulkan, dan mencontek ke teman, karena siswa tidak belajar dengan serius maka dari itu banyak nilai siswa yang turun karena belajar yang dilakukan tidak maksimal selama system pembelajaran kombinasi daring/luring ini. bahwa:

Hal ini juga dikatakan oleh Bapak SR selaku wakil kesiswaan SMA Negeri 1 Ranah Pesisir

"... selama pembelajaran di masa Covid-19 ini baik pembelajaran daring atau luring banyak nilai siswa yang turun...” (Wawancara 8 April 2021).

Hal tersebut juga di ungkapkan oleh Ibu YN selaku guru mata pelajaran sosiologi, beliau mengungkapkan bahwa:

“...selama pandemi Covid-19 ini banyak nilai siswa yang turun karena siswa tidak serius dalam belajar dan juga pada ujian banyak siswa mengumpulkan kertas kosong dan semabarangan mengisi ujian sehingga ibu pusing bagaimana cara siswa supaya nilainya tuntas sudah ibu kasih remedy untuk tugas tapi siswa tetap tidak mengerjakan tugas, dan nilai siswa tetap rendah sii..." (Wawancara 8 April 2021).

\section{Hal serupa juga dikatakan oleh Siswa kelas DN kelas XI IPS}

“... banyak nilai siswa rendah karena banyak tugas sehingga siswa malas untuk membuat tugas sehingga nilai seadanya..." (Wawancara 7 April 2021).

Berdasarkan wawancara peneliti dengan informan diatas dapat peneliti simpulkan bahwa selama pembelajaran kombinasi daring/luring berlangsung pada mata pelajaran sosiologi dengan cara siswa banyak yang malas sekolah dan malas belajar serta banyak siswa yang tidak mengerjakan tugas baik pada pembelajaran daring maupun pembelajaran luring maka guru mata pelajaran dapat membedakan nilai siswa maka guru mata pelajaran dapat melihat perbedaan nilai siswa pada masa pandemi Covid-19, diantaranya banyak nilai siswa yang rendah sehingga tidak tuntas mencapai 50\%. Sehingga guru mata pelajaran sulit untuk mengolah nilai siswa sosiologi.

\section{Siswa tidak mampu membeli paket internet.}

Pembelajaran daring pada mata pelajaran sosiologi memerlukan kouta internet untuk melaksanakan pembelajaran melalui aplikasi media whatssapp namun dalam pelaksanaan banyak siswa sosiologi yang terkendala dalam pelaksanaan pembelajaran daring sosiologi karena banyak tidak mampu untuk membeli kouta internet, karena ada diantaranya orang tua siswa memiliki ekonomi yang rendah sehingga kesulitan untuk membeli kouta internet. Hal ini juga diungkapkan oleh YN selaku guru mata pelajaran sosiologi beilau mengatakan bahwa:

“... siswa banyak tidak mampu membeli kouta internet yosi karena orang tua mereka ada yang tidak mempunyai uang sehingga, siswa mengeluh ketika pembelajaran daring dengan tidak ada paket internet yang mereka miliki..." (Wawancara 8 April 2021)

Hal tersebut juga diungkapkan oleh VI selaku siswa kelas XI IPS 2 yang mengatakan bahwa:

" ... tidak ada uang untuk membeli kouta internet kak, orang tua kami tidak mampu membelikan kuota internet kak..." (Wawancara 7 April 2021). 
Yosi Azari, Delmira Syafrini, Nurlizawati Nurlizawati Problematika Sistem Pembelajaran Kombinasi Daring dan Luring

Jadi berdasarkan wawancara peneliti dapat peneliti simpulkan bahwa dalam pembelajaran daring siswa tidak bisa mengikuti pembelajaran karena ada beberapa siswa diantaranya tidak memiliki kouta internet karena factor ekonomi, ada siswa berasal dari factor ekonomi orang tua yang rendah sehingga tidak mampu untuk membeli kouta internet dan pada akhirnya siswa tidak bisa mengikuti belajar daring.

Kesulitan siswa dalam mengakses internet. Kabupaten Pesisir Selatan khususnya didaerha Kecamatan Ranah Pesisir maish banyak daerah yang susah akses interntet, sementara itu berpengaruh kepada proses siswa belajar secara daring ada sekitar 30\% siswa sosiologi yang memiliki susah akses sinyal internet oleh karena itu dalam pelaksanaan pembelajaran daring yang sedang berlangsung diantaranya siswa kelas XI IPS sosiologi banyak siswa tidak mengikuti pembelajaran karena alasan kesulitan untuk mengakses jaringan internet di daerah siswa yang tidak memiliki sinyal.

Hal ini juga diungkapkan oleh Ibu YN selaku guru sosiologi, beliau mengatakan bahwa:

“... Banyak siswa sosiologi yang tinggal di daerah tidak ada jaringan internet, banyak siswa diantaranya tidak bisa mengirim tugas online karena siswa harus mencari jaringan keluar daerah terlebih dahulu..." (Wawancara 7 April 2021).

Hal tersebut juga diperkuat oleh YS (16 Tahun) selaku siswa kelas XI IPS 3, yang mengatakan bahwa:

"... Tidak bisa saya belajar online di rumah, karena di rumah saya susah untuk mengakses jaringan kak, dan saya harus pergi dulu ketempat yang ada jaringannya kak..." (Wawancara 7 April 2021)

Jadi dapat peneliti simpulkan berdasarkan wawancara peneliti dengan informan bahwa ada diantaranya siswa yang mana daerahnya tidak memiliki akses internet, berdasarkan hal itu siswa belajar online atau membuat tugas harus pergi dulu keluar daerah yang mana ada tempat akses jaringan.

\section{Problematika Sistem Pembelajaran Kombinasi Daring/Luring Yang Dirasakan Oleh Guru}

\section{Guru tidak pengalaman menerapkan pembelajaran kombinasi.}

Berdasarkan obeservasi peneliti di SMA Negeri 1 Ranah Pesisir bahwa guru sosiologi ketika pembelajaran daring guru hanya memberikan tugas kepada siswa ketika pembelajaran luring, dan siswa belajar secara mandiri dirumah dengan membuat tugas, ketika pembelajaran luring guru hanya menerangkan materi kepada siswa dan berdiskusi bertanya kepada siswa materi mana yang tida mengerti, sehingga pembelajaran tidak terlaksana dengan baik dan tidak melaksanakan pembelajaran daring dengan baik. Guru masih menggunakan cara belajar, oleh karena itu guru belum bisa menggunakan teknologi dan belum mahir dalam menggunakan teknologi sehingga pembelajaran daring siswa hanya mengerjakan tugas. Berdasarkan hal itu dianalisis dengan Teori belajar dengan konsep teori belajar sibernetik yang dikemukakan oleh landa (Budiningsih, 2005) Landa merupakan salah seorang psikologi yang beraliran sibernetik.

Teori belajar sibernetik dalam sistem pembelajaran kombinasi daring/luring yakni guru dan siswa, harus mampu mengetahui dua hal yaitu materi pelajaran dan pola pikir siswanya. Ketika guru memberikan materi pembelajaran secara daring melalui aplikasi whatssapp group guru harus mampu menyesuaikan diri dengan siswa walaupun dalam keadaan tidak berada di dalam kelas, dan siswa tidak harus bertatap muka langsung seperti pembelajaran yang dilakukan saat ini yaitu pembelajaran daring yang mana guru dan siswa tidak bertatap muka (Anwar, 2017).

Hal serupa juga dikatakan Bapak SR, beliau mengatakan bahwa:

"... Banyak guru yang tidak paham dengan pembelajaran kombinasi ini, guru belum pernah menerapkan pembelajaran selama ini..." (Wawancara 7 April 2021). 
Yosi Azari, Delmira Syafrini, Nurlizawati Nurlizawati Problematika Sistem Pembelajaran Kombinasi Daring dan Luring

Hal tersebut juga diperkuat oleh Ibu YN selaku guru mata pelajaran sosiologi, beliau mengatakan bahwa:

"... Jujur saja ibu belum paham dengan pembelajaran yang diterapkan, karena sebelumnya pembelajaran kombinasi daring/luring ini belum pernah dilaksanakan, sehingga masih menggunakan metode belajar yang lama, yang mana siswa bisa belajar dengan memberi tugas bacaan di rumah, lalu dijelaskan pada pembelajaran luring, itu cara ibu supaya pembelajaran terlaksana di masa pandemi Covid-19 ini..." (Wawancara 8 April 2021).

Hal serupa juga dikatakan oleh ND selaku kelas XI IPS, yang mengungkapkan bahwa: "... Ibu yel masih menggunakan cara belajar seperti biasa kak, belajar daring kami membuat tugas di rumah kak, kalau tatap muka ibu menjelaskan materi kak." (Wawancara 7 April 2021).

Jadi dapat peneliti simpulkan bahwa guru belum siap untuk melaksanaakan pembelajaran yang dianjurkan pemerintah tetapi mau gimana lagi harus bisa melaksanakan pembelajaran tersebut dengan berbagai keterbatasan, karena guru sudah terbiasa dengan pembelajaran yang sebelum adanya pandemi Covid-19, pembelajaran kombinasi secara mendadak sehingga guru tidak memiliki pengetahuan untuk pembelajaran kombinasi daring/luring ini.

\section{Guru kesulitan dalam memberikan penilaian selama pembelajaran kombinasi daring/luring.}

Problematika dalam memberikan penilaian terhadap siswa, guru memiliki kendala dalam memberikan penilaian terhadap proses pembelajaran kombinasi daring/luring karena ada beberapa hal seperti kesulitan memberikan penilaian terhadap tugas yang diberikan kepada siswa karena guru ragu terhadap tugas yang siswa buat di rumah, karena banyak contekkan dan siswa tidak berpikir sendiri. (Harahap \& Purwanta, 2021). Hal tersebut merupakan permasalahan bagi guru sosiologi dalam menilai tugas yang diberikan kepada siswa karena tugas terkadang tidak siswa sendiri yang membuatnya. Berdasarkan hal itu karena guru harus memperhatikan prinsipprinsip penilaian dalam penilaian yang merupakan harus komprensif (menyeluruh), berkesinambungan, objektif, penialaian atas dasar alat ukur yang valid, serta bermakna (Depdiknas, 2002).

Oleh karena itu berdasarkan wawancara peneliti dengan guru mata pelajaran sosiologi bahwa guru sosiologi menilai siswa berdasarkan keaktifan siswa dalam belajar di kelas, seperti diskusi dikelas, dan tugas individu, dan menjawab pertanyaan yang diberikan, kuis yang diadakan dikelas.

Hal tersebut juga diungkapkan oleh Ibu YN selaku guru mata pelajaran sosiologi, beliau mengatakan bahwa:

“... Ibu mengakui, ibu sangat sulit memberikan penilaian dalam proses pembelajaran daring/luring ini yosi, ditambah lagi siswa tidak aktif dalam pembelajaran sehingga ibu bisa menilai bisa beradasrakan keaktifan siswa di kelas, kehadiran siswa dan cara bersikap, dipembelajaran daring ibu hanya bisa menilai siswa berdasarkan tugas dikumpulkan, bukan berdasarkan isi tugas yang dibuat siswa dan sangat banyak sekali siswa yang remedy tugas karena ibu bingung harus ambil nilai siswa dari mana, tugas yang diberikan tidak dikerjakan, kehadiran terkadang hadir terkadang tidak..." (Wawancara 7 April 2021). Tahun):

Berdasarkan wawancara peneliti diatas maka, hal tersebut diperkuat oleh siswa kelas YS (16

“... Ibu yel menilai kami dengan cara kami buat tugas kak, terus siapa yang menunjuk tangan untuk kuis maka dikasih nilai kak, kalau tidak aktif di kelas tidak tau ibu cara 
Yosi Azari, Delmira Syafrini, Nurlizawati Nurlizawati Problematika Sistem Pembelajaran Kombinasi Daring dan Luring

menilai dari mana kak, karena pembelajaran daring juga susah kak..." (Wawancara 7

April 2021).

Berdasarkan wawancara peneliti dengan informan dapat peneliti simpulkan bahwa guru mata pelajaran sosiologi merasa kesulitan dalam memberikan penilaian pada pembelajaran kombinasi daring/luring ini, karena siswa banyak tidak aktif dalam belajar maka penilaian diambil guru mata pelajaran sosiologi ketika pembelajaran luring atau tatap muka dan guru mata pelajaran mengambil nilai berdasarkan siswa yang aktif ketika di kelas.

\section{Tidak efektifnya waktu mengajar guru}

Pada pembelajaran kombinasi yang diterapkan pada mata pelajaran sosiologi di SMA Negeri 1 Ranah Pesisir, sesuai dengan surat edaran Bupati Pesisir Selatan tentang pelaksanaan pembelajaran pada tahun 2020/201 bahwa diperbolehkan melaksanakan pembelajaran tatap muka dengan watu pembelajaran diperpendek 1 jam menjadi 30 menit. Berdasarkan hal itu pada pelaksanaan pembelajaran daring tidak efektif siswa hanya belajar mandiri di rumah dan membuat tugas di rumah materi pelajaran tidak dijelaskan oleh guru, belajar di rumah tidak dikontrol oleh guru sehingga waktu yang digunakan tidak efektif, pada pembelajaran luring guru menjelaskan materi pembelajaran daring dan luring dua materi sekaligus dengan waktu yang pendek 30 menit sehingga materi pelajaran tidak tercapai dan terkendala dalam menyampaikan materi dengan hal itu ketika pembelajaran luring guru juga melaksanakan diskusi dengan siswa, ada proses tanya jawab, dan juga memberi waktu kepada siswa untuk bertanya bagian materi mana yang tidak dipahami. Sehingga dengan hal itu maka ada materi ada yang tertinggal karena terbatas oleh waktu, yang mana siswa juga tidak mengerti dengan materi pembelajaran daring dan mengharuskan siswa untuk bertanya kepada guru tentang pelajaran tersebut sehingga terkendala dan waktu tidak cukup untuk pembelajaran.

Hal ini juga diungkapkan oleh YN guru mata pelajaran sosiologi kelas XI IPS.

“... Pada pembelajaran daring/luring ini waktu belalar 1 jam 30 menit, sedangkan pada pelajaran daring siswa sama sekali tidak belajar, dan ibu menjelaskan materi ketika belajar tatap muka di kelas baik itu materi daring dan luring dua materi Ibu jelaskan dan tidak tercapai menjelaskan materi karena waktu pendek, dan ada juga siswa tidak mengerti lalu bertanya, dan terkendala karena waktu belajar pendek untuk saat ini sehingga belajar terbengkalai materinya dan disambung lagi 2 minggu, sehingga siswa juga bosan dengan materi itu-itu saja..." (Wawancara 8 April 2021)

Hal tersebut juga diperkuat oleh, AN (16 Tahun), mengatakan bahwa:

"... Jam belajar hanya 30 menit kak, dan materi kadang tidak sampai kak, ada juga diskusi, dan dijelelaskan tampil 2 kelompok jam pelajaran habis lalu di sambung lagi 2 minggu lagi kak, jadi pelajaran itu-itu saja kak..." (Wawancara 7 April 2021).

Jadi berdasarkan wawancara peneliti dengan informan bahwa, jam pelajaran singkat 1 jam 30 menit sehingga materi pelajaran tidak dapat disampaikan sesuai target, dan guru mata pelajaran menyampaikan materi dua materi sekaligus dengan waktu 30 menit karena pembelajaran daring tidak efektif maka dapat pembelajaran luring menjelaskan materi dua materi sekaligus.

\section{Kemampuan guru sosiologi menggunakan teknologi terbatas.}

Pada proses pembelajaran kombinasi daring/luring guru dan siswa hanya bisa memanfaatkan teknologi yang bisa dipakai selama pandemi Covid-19, yaitu aplikasi WhatsApp, Google Classroom, Zoom, Yang disediakan oleh sekolah, berdasarkan hal itu guru sosiologi di SMA Negeri 1 Ranah Pesisir hanya mampu menggunakan aplikasi whatsaap group dalam proses pembelajaran. 
Yosi Azari, Delmira Syafrini, Nurlizawati Nurlizawati Problematika Sistem Pembelajaran Kombinasi Daring dan Luring bahwa:

Hal ini dikatakan oleh Bapak SR (35 Tahun) selaku wakil kurikulum yang mengatakan

“... Tidak semua guru yang mampu menggunakan teknologi informasi, diantaranya banyak guru yang gagal teknologi apalagi guru yang cendrung agak tua, kebanyakkan guru hanya menggunakan aplikasi whatssapp group lebih mudah dipahami..." (Wawancara 8 April 2021).

Hal diatas juga diungkapkan oleh Ibu YN (40 Tahun), beliau mengatakan bahwa:

"... Kita dalam pembelajaran hanya bisa menggunakan whatssaap group dalam melaksanakan pembelajaran..." (Wawancara 8 April 2021).

Berdasarkan wawancara yang peneliti lakukan dengan Bapak SR dan Ibu YN, beliau hanya menggunakan aplikasi Whatsaap group dalam melaksanakan proses pembelajaran kombinasi daring/luring. Hal ini disebabkan karena guru sosiologi belum bisa menggunakan aplikasi pembelajaran yang lain dan menurut beliau bahwa aplikasi whasstaap group mudah digunakan dan sudah biasa digunakan baik guru maupun siswa.

\section{Keterbatasan sarana dan prasarana.}

Pelaksanaan pembelajaran kombinasi/daring luring harus memiliki srana dan prasarana yang lengkap, di SMA Negeri 1 Ranah Pesisir melaksanakan system pembelajaran kombinasi dengan sarana prasarana terbatas, seperti buku terbatas, sekolah tidak menyediakan fasilitas seperti jaringan wifi.id ketika pembelajaran daring. Sehingga guru sulit untuk mengakses internet dan mencari bahan pembelajaran melalui internet, dan juga guru dan siswa juga tidak mendapatkan bantuan paket internet. Karena hal itu merupakan salah satu problematika dalam pelaksanaan pembelajaran pada pandemi Covid-19.

Berdasarkan hal itu juga disampaikan oleh Ibu YN selaku guru mata pelajaran sosiologi, beliau mengatakan bahwa:

“... Sekolah tidak memiliki buku paket sosiologi yang lengkap, terkadang ada materi, terkadang gak ada materi di dalamnya, dan sekolah juga tidak menyediakan paket data untuk guru, apalagi wifi.id tidak disediakan, selama pembelajaran daring ini memori handphone ibu cepat penuh, sehingga siswa mengumpulkan tugas tidak bisa karena memori handphone tidak muat lagi..." (Wawancara 8 April 2021).

Berdasarkan hasil wawancara Ibu YN dapat dipahami bahwa sekolah tidak memiliki fasilita yang memadai untuk penerapan system pembelajaran kombinasi daring/luring baik guru maupun siswa. Berdasarkan analisis teori struktural fungsional AGIL, menurut teori ini sesuai dengan jika rusak suatu sistem maka juga akan rusak sistem yang lainnya, karena dalam pelaksanaan pembelajaran kombinasi daring/luring ini sistem pembelajaran tidak berjalan dengan baik maka juga berpengaruh dengan sistem pembelajaran yang dilaksanakan oleh siswa dan guru.

Berdasarkan hasil penelitian yang peneliti temukan, dikuatkan dengan beberapa penelitian tentang Problematika System Pembelajaran Pada Masa Pandemi Covid-19 ini. Menurut penelitian yang dilakukan oleh Andi Asywid Nur yang berjudul problematika guru dalam pembelajaran daring di tengah Pandemi Covid-19. Hasil penelitian menunjukkan bahwa permasalahan yang dialami guru dalam melaksanakan system pembelajaran pada masa pandemi Covid-19 ini tentu ada penerapan pembelajaran dilakukan tidak ada persiapan yang mana pembelajaran dilaksanakan secara mendadak sehingga guru tidak mampu menyesuaikan secara cepat untuk melaksanakan system pembelajaran.

Selanjutnya penelitian dilakukan Nur Millati Aska yang berjudul problematika pembelajaran daring. Hasil penelitian ini menunjukka bahwa pembelajaran daring merupakan pembelajaran yang dilakukan secara online tanpa tatap muka, yang mana pada penerpan pembelajarannya guru dan siswa tidak begitu pandai dalan teknologi banyak diantaranya gagal teknologi (GAPTEK). 
Yosi Azari, Delmira Syafrini, Nurlizawati Nurlizawati Problematika Sistem Pembelajaran Kombinasi Daring dan Luring

Berdasarkan hasil penelitian yang telah peneliti lakukan, dapat disimpulkan bahwa system pembelajaran kombinasi daring/luring pada mata pelajaran sosiologi memiliki kendala, seperti kurangnya motivasi peserta didik untuk belajar, terlihat bahwa dalam pelaksanaan pembelajaran tidak efektif maka peserta didik merasa diberatkan dalam pembelajaran karena pada pembelajaran daring tidak efektif, pada pembelajaran luring peserta didik banyak malas serta tidak menegrjakan tugas dan tidak mengikuti pembelajaran. Bagi guru, guru kesulitan dalam memberikan penilaian kepada siswa karena siswa banyak tidak mengikuti pembelajaran maka guru susah untuk memberikan penilaian kepada siswa.

\section{Kesimpulan}

Berdasarkan hasil penelitian yang peneliti lakukan terhadap problematika sistem pembelajaran kombinasi daring/luring pada mata pelajaran sosiologi kelas XI IPS di SMA Negeri 1 Ranah Pesisir. Di peroleh kesimpulan yaitu Problematika sistem pembelajaran kombinasi daring/luring pada mata pelajaran sosiologi yang berasal dari guru dan siswa diantaranya problematika yang dialami guru adalah guru sosiologi tidak memiliki skill/pengetahuan terhadap sistem pembelajaran kombinasi, guru kesulitan dalam memberikan penilaian selama pembelajaran kombinasi diterapkan, tidak efektifnya waktu belajaran guru, kualitas jaringan tidak memadai, kurangnya sarana dan prasarana, dan serta problematika yang, berasal dari siswa, siswa kesulitan dalam menyesuaikan diri terhadap pembelajaran kombinasi, keterbatasan sarana dan prasarana, kurangnya motivasi siswa dalam belajaran, hasil belajar siswa rendah, tidak mampu siswa dalam membeli paket internet, tidak efektifnya waktu belajar siswa.

\section{Daftar Pustaka}

Anwar, C. (2017). Teori-teori Pendidikan Klasik Hingga Kontemporer. Yogyakarta: IRCISod.

Arikunto, S. (2016). Prosedure Penelitian Suatu Pendekatan. Jakarta: Rineka Cipta.

Asmuni, A. (2020). Problematika Pembelajaran Daring di Masa Pandemi Covid-19 dan Solusi Pemecahannya. Paedagogy: Jurnal Penelitian Dan Pengembangan Pendidikan, 7(4).

Budiningsih, A. (2005). Belajar dan Pembelajaran. Jakarta: Rineka Cipta.

Dewi, W. A. F. (2020). Dampak COVID-19 terhadap Implementasi Pembelajaran Daring di Sekolah Dasar. Edukatif: Jurnal Ilmu Pendidikan, 2(1), 55-61.

Harahap, S. A., \& Purwanta, E. (2021). Problematika Pembelajaran Daring dan Luring Anak Usia Dini bagi Guru dan Orang tua di Masa Pandemi. Jurnal Pendidikan Anak Usia Dini, 5(2), 1825-1836. https://doi.org/10.31004/obsesi.v5i2.1013

Putria, H., Maula, L. H., \& Uswatun, D. A. (2020). Analisis Proses pembelajaran Dalam Jaringan

(Daring) Masa Pandemi COVID-19 pada Guru Sekolah Dasar. Jurnal Basicedu, 4(4), 861872. https://doi.org/10.31004/basicedu.v4i4.460

Ritzer, G., \& G. (2008). Teori Sosiologi Modren Edisi Keenam. Jakarta: Kencana.

Subayo, J. (2006). Metode Penelitian dan Praktek. Jakarta: PT. Rineka Cipta.

Sugiyono, S. (2015). Metode Penelitian Pendidikan. Bandung: Alfabeta.

Sugiyono, S. (2017). Metode Penelitian Kuantitatif, Kualitatif, dan R\&D. Jakarta: Alfabeta.

Wahyuningsih, K. S., Hindu, U., Gusti, N. I., \& Sugriwa, B. (2021). Problematika Pembelajaran Daring di Masa Pandemi Covid-19 di SMA Dharma Praja Denpasar. Pangkaja, 24(1), 107-118. 